DOI: 10.20472/IAC.2017.030.008

\title{
NICOLETA-ELENA BUZATU
}

1, Romania

\section{MEDIATION IN THE CASE OF DISRESPECTING MEASURES CONCERNING THE CUSTODY OF THE MINOR}

\begin{abstract}
:
In criminal cases relating to offences for which, according to the law, the withdrawal of the preliminary complaint removes the criminal liability, mediation may be the best solution for the parties to reach an out-of-court-settlement. The defendant or the injured party, if interested in solving the situation faster or recovering the injury, will initiate the criminal mediation proceeding by addressing a mediator. Failure to comply with measures regarding child custody presupposes that a minor child is retained by one parent, without the consent of the other one, or repeatedly prevents a parent from getting in touch with the child. The Criminal Code stipulates that this kind of offences is initiated upon the complaint of the injured person - for which mediation agreement completely removes criminal liability. In this case mediation can take place at any time during the criminal proceedings, including the appeal stage.
\end{abstract}

\section{Keywords:}

mediation, preliminary complaint, mediation agreement, criminal liability, minor

JEL Classification: K14, K40 


\section{Introduction}

The criminal law seeks to sanction those who commit grave illicit actions. Across time, this repressive, punitive trait has diminished under the influence of the concept of restorative or reparatory justice. The main purpose of this concept is to repair the damage caused to the victim, community or even the offender through the crime committed.

The concept of restorative justice implies making the offender responsible, involving the victim and the community in the act of justice, repairing the damages caused to the victim and the community and reestablishing the social order that was diminished by the crime 1 .

In Romania, the legal frame of victim-offender mediation was instituted through the 192/2006 Law concerning mediation and the organization of the mediator profession². Other laws that concern criminal mediation can be found in the Romanian Criminal Procedure Code.

Mediation represents, according to article 1 of the above mentioned law, a way of solving conflicts through amenable understanding, with the help of a specialized third party acting as mediator, in conditions of neutrality, impartiality, confidentiality and with the free consent of the parties.

Penal conflict mediation has been defined in the Romanian penal doctrine ${ }^{3}$ as a "means of communication, based on exchanges and consideration of each other, in a dialogue designed to establish an agreement, in connection with existing institutions, found by the parties themselves and considered as satisfactory for both, all this in the presence of a third party".

Mediation is possible for crimes where it is necessary for the victim to make a preliminary complaint in order to set in motion the penal action and also for crimes where reconciliation of the parties is possible.

In criminal trials, mediation can have two variations: civil and criminal.

a. Civil mediation in a criminal trial concerns only the civil action and represents in actuality a transaction intermediated by the mediator that concerns only the reparations demanded by the parent who has been entrusted with the custody of the minor, and in the iteration described in paragraph (2), the parent of the minor when his custody was given to a person other than the parents, to be raised and educated, in order to repair damages caused by the crime. Such a mediation agreement will not stop the course of the penal side of the trial, but will eventually influence the solution given in the penal action.

\footnotetext{
${ }^{1}$ FISCUCI, I.C. (2012). Aspecte particulare în aplicarea medierii în disputele din domeniul penal, Revista Română de ADR, no 1, p. 23.

2 Published in Official Gazette of Romania, Part I, no 441 from 22 May 2006, with ulterior modifications.

${ }^{3}$ MATEUȚ, G. (2007). Medierea penală, in Dreptul no 7, p. 149.
} 
b. Penal mediation is a restorative practice that implies a dialogue between victim and offender. Neither one can be constrained to resort to mediation. The parties are not obligated to inform themselves prior to mediation and there is no sanction for refusing to use this procedure.

Concerning the crime, according to article 15 paragraph (1) of the Romanian Penal Code, it represents the action described by the criminal law, undertaken with guilt, unjustified and imputable on the person that committed it. According to paragraph (2) of the same article, a crime is the only legal grounds for penal responsibility.

According to article 32 of the Romanian Criminal Procedure Code, the parties are procedural subjects that use or against which a judicial action is used, meaning the defendant, the civil party and the civilly responsible party.

The defendant is the person or legal entity against which the penal action has been set in motion (article 82 of the Romanian Criminal Procedure Code).

The civil party is the injured party (person or legal entity) which uses the civil action within the criminal trial. The successors of the injured party are also considered civil parties, if they use the civil action within the criminal trial (article 84 of the Romanian Criminal Procedure Code).

The civilly responsible party is the person who, according to civil law, has the legal or conventional obligation to repair, either fully or partially, alone or in solidarity, the damages caused by the crime and who is called to answer in the trial, is part of the penal trial and is called civilly responsible party (article 86 of the Romanian Criminal Procedure Code).

The procedural subjects are primary, meaning the suspect and the victim and other procedural subjects, meaning the witness, expert, procedural agent, special ascertainment bodies, any other person or body mentioned by the law, with certain rights and obligation in the criminal judicial proceedings (article 34 of the Romanian Criminal Procedure Code).

The suspect is the person that is considered, given the facts and evidence of the case, to be reasonably possible to have committed the action mentioned in criminal law (article 77 of the Romanian Criminal Procedure Code). He is not a party in the criminal trial and he is also not a subject of the penal action, he is however a primary procedural subject, with procedural rights and obligations, expressly mentioned by the law.

The injured party is the person that suffered physical, material or moral damages through the criminal action (article 79 of the Romanian Criminal Procedure Code). He is not part of the criminal trial, he is however a primary procedural subject, with procedural rights and obligations, expressly mentioned by the law. 
In our case, the parties involved in the process of mediation are the parent of the minor or the person to whom the minor's custody was entrusted and the parent who was given custody or the parent of the minor, when his custody was given to a different person, besides the parents, for raising and educating.

Therefore, only the parties and the primary procedural subjects can be involved in the mediation procedure and no other procedural subject such as witnesses, experts, interpreters, procedural agents, special ascertainment bodies. This way, there can be no confusion between the notion of parties in the mediation or the mediation agreement and that of parties in the criminal trial. Thus, when we talk about the mediation procedure, we will use the terminology victim-offender or victim-criminal, or parties, but not in a procedural sense.

During the solving of a penal case, the one who is presumed to have committed the crime is granted a series of names which allow an observer to determine the stage at which the judicial proceedings have arrived at and to determine the rights and obligations of the person in question, as follows:

- Before triggering the criminal trial, the one who committed the deed is known as offender;

- Once the prosecution has started in personam, the offender becomes the suspect (article 305, paragraph $<3>$ of the Romanian Criminal Procedure Code);

- Once the penal action has started, the suspect becomes the defendant.

Because the 192/2006 Law concerning mediation and the organization of the mediator profession states that during mediation the parties can be represented by other people who can undertake disposition acts according to the law, we understand that during the mediation procedure parties can use conventional representation. Because the law mentions the possibility to undertake disposition acts according to the law, it is necessary to craft a special procedure. The special dispositions within the object of penal mediation does not limit this right of representation, which leads us to believe that conventional representation is allowed in penal mediation as well ${ }^{1}$.

The representatives are those people authorized to participate in the completion of procedural activities in the name and interest of one of the parties or one of the primary procedural subjects in the trial. They are not considered parties in the trial, they are simple procedural subjects, fulfilling procedural acts within the penal judicial activity in the name and interest of other people.

${ }^{1}$ DRAGNE, L.; TRANCĂ, A. (2011). Medierea în materie penală. Bucureşti: Universul Juridic Publishing House, p. 111. 


\section{Crime analysis}

In the Romanian Penal Code, crimes against the family are positioned in Chapter II, Title VIII dedicated to crimes which violate relations concerning social cohabitation.

In the Special Part of the same code, crimes that carry the mention "the penal action is set in motion with the preliminary complaint of the victim", number at 25 , among which there is the crime of disrespecting measure concerning the custody of the minor - article 379.

\subsection{Legal regulation}

Article 379 of the Romanian Penal Code, disrespecting the measure concerning custody of the minor, mentions the following:

(1) The detention by one of the parents of his minor child, without the consent of the other parent or of the person to whom the child was given custody of according to the law, is punishable by prison from 1 to 3 month or by fine.

(2) The same punishment is applicable to the person who has been granted custody of the minor through court ruling to raise and educate that forbids, repeatedly any of the parents from having personal relations with the minor, according to the terms set by the parties of by the competent body.

Because paragraph (3) mentions expressly that "the penal action is set in motion with the preliminary complaint of the injured party", withdrawing this complaint leads to the removal of penal responsibility.

The family is a type of social life organization based on marriage or kinship. ${ }^{1}$ The family is a social reality through the communion of life between the husbands, parents, children, relatives ${ }^{2}$.

Keeping in mind that the normal unfolding of family relations condition the life, health and rights of the family members, the defense of these relations must be effectively enforced.

The Romanian Constitution mentions in article 49, paragraph (1): children and young adults enjoy a special regime of protection and assistance towards the realization of their rights.

As is stipulated in article 483 of the Romanian Civil Code, parents exert parental authority only in the best interest of the child, respecting that person and involving the child in all

\footnotetext{
${ }^{1}$ POPESCU, T. (1965). Dreptul familiei. Tratat, vol. I. Bucureşti: Didactică şi Pedagogică Publishing House, p. 17. 2 IONAŞCU, A.; MUREŞAN, M.; COSTIN, M.; URSA, V. (1975) Familie şi rolul ei în societate. Cluj: Dacia Publishing House, p. 5.
} 
decisions that concern him, given his age and degree of maturity, both parents being held accountable for the raising of their minor child ${ }^{1}$.

The major importance of this law can be seen from the beginning, the principle of having the best interest of the child in mind as well as protecting his rights, not letting these fall in disregard because of conflicts between the parents or between the parents and the people who exert parental authority, or at the domicile of the minor.

\section{The object of the crime}

The special judicial object consists of social relations which assure normal conditions for the raising and educating of the minor, even if the parents are separated.

The material object of the crime is the minor person, who is forbidden to physically interact with one of the parents by the other.

\section{The subject of the crime}

The subjects of the crime are traditionally classified as: active subject of the crime - the author of the criminal act, and passive subject - the party injured in a direct way by the crime. Moreover, in the case of any action mentioned by the penal law, alongside the injured party we have the state, as general passive subject of the crime because it is always harmed through the undertaking of criminal actions against the social order.

The active subject is qualified. It can be only the person considered a parent of the minor in the variation mentioned in paragraph (1) or the person who is entrusted with the custody of the minor in the variation mentioned in paragraph (2).

The passive subject of the crime of disrespecting measures concerning the custody of the minor can be in the iteration mention in paragraph (1) the parent who the minor was entrusted to and in the iteration from paragraph (2) the minor's parent, when the minor's custody was given to a different person other than his parents to raise and educate.

Therefore, mediation takes place between the parent of the minor or the person to whom the custody of the minor was given (active subject) and the parent who was given custody or the parent of the minor, when he has entrusted to another person to raise and educate (passive subject), other than the parents.

\subsection{Constitutive content}

1 TOMESCU, M; MURARU, I.; TĂNĂSESCU, E.S. (2008). Constituția României. Comentariu pe articole. Bucureşti: C.H. Beck Publishing House, București, p. 496. 
The objective side. The material element consists in the action of detaining the minor by one the parents, without the consent of the other or of the person who was granted custody of the minor according to the law or the action of preventing any of the parents from having relations with the minor.

The essential requirement of the material element of the crime in the variation mentioned in article 379, paragraph (1) of the Romanian Penal Code is that the detainment of the minor take place without the consent of the other parent or of the person who was granted custody ${ }^{1}$.

In the variation mentioned by article 379, paragraph (1) of the Romanian Penal Code, it is required that the action take place repeatedly, and not be singular. It is also necessary for the prevention to be contrary to the terms established by the parents or by the competent body in regard to the way in which parents maintain personal relations with the minor ${ }^{2}$.

This situation must not be confused with that in which the parent who did not receive custody, kidnaps the minor, takes him from the care of the parent who was entrusted with custody against his will. In this case, the crime committed is that of unlawful detainment article 205 of the Romanian Penal Code.

\section{The immediate effect}

This crime does not imply the materialization of a result, even though the deterioration of relation between the child and one of the parents inevitably takes place. In both variations, the state of danger consists of endangering the growth and education of the child, but also in the deterioration of relations between the child and one or both of the parents, which determines unwanted social effects.

The subjective side. In both variations of the crime, it is done with direct or indirect intent, which means that the offender realizes he is disregarding the measures concerning the custody of the minor and foresees that detaining the minor without the consent of the parent or the person entrusted with custody and preventing the child from having relations with his parents prohibits his normal growth and education, but pursues or accepts the realization of these consequences.

\subsection{Variations. Modalities. Sanctions}

Variations. Both preliminary acts and the attempt are possible, but they are not punished. The crime of disrespecting the measure concerning the custody of the minor is complete

1 OANCEA, I. în DONGOROZ, V. și colab. (2003). Explicații teoretice ale Codului penal român. Partea specială, vol. IV, ed. a 2-a, Bucureşti: All Beck Publishing House, p. 521.

2 Idem. 
in the moment when the repeated detainment or prevention of the minor to have relations with his parents took place.

Modalities. The typical or simple form of the crime is incriminated in two iterations and specifically the one mentioned in paragraph (1) the detainment of the minor and that mentioned in paragraph (2) the prevention of the minor from having personal relations with the parents. The law does not mention any aggravating circumstance for the crime, but the act can have the modality of the specific manner in which it took place, a fact which will be taken in consideration when deciding the punishment. ${ }^{1}$

Sanctions. This crime is punishable by prison from 1 to 3 months or by fine in any of the variations.

\subsection{Procedural aspects}

The penal action is set in motion with the preliminary complaint of the injured party. The prosecution is undertaken by the criminal investigation bodies and the competency to judge in first instance belongs to the court.

\section{Mediation of the crime of disrespecting the measures concerning the custody of the minor depending on the procedural stages}

Mediation is possible for crimes that require a preliminary complaint from the injured party to set in motion the penal action as well as for crimes that allow the reconciliation of the parties. According to the ruling of the Romanian Constitutional Court nr. 397/2016, mediation can be done for crimes that require a preliminary complaint and implicitly the withdrawal of the complaint throughout the criminal trial until the definitive ruling of the court and for crimes that allow reconciliation, mediation can take place only till the reading of the notification act.

Mediation in the case of disrespecting the measures concerning the custody of the minor leads to the removal of penal responsibility. Mediation can take place anytime until the definitive ruling of the court because it is a crime for which the penal action is set in motion by the preliminary complaint of the injured party.

1 Idem. 


\subsection{Mediation during the prosecution}

Between the crime taking place and the punishment there is a criminal trial started by society (the Public Ministry) when the lawful order has been breached, started against the author of the crime with the intent of punishing him according to the law. ${ }^{1}$

The criminal trial is the activity governed by the law, undertaken for a criminal case by the judicial bodies with the participation of the parties and other people, as entitled by right and obligation, with the purpose of timely and complete ascertainment of the crimes and holding those guilty accountable for their actions, in such a way as to guarantee the lawful order as well as the defense of rights and legitimate interests of the people. ${ }^{2}$

The criminal trial has three stages: the prosecution, the trial and carrying out the sentence; during this debate we will analyze the mediation procedure based on procedural moments to which the legislator refers to, specifically the drafting of the preliminary complaint and the beginning of the prosecution and not the three stages mentioned above.

The preliminary complaint institution is considered as an exception from the principle ex officio and consists of the possibility given by the law to the injured party to decide if the notification of the criminal prosecution bodies should take place or not and to decide whether to hold the offender responsible or not. ${ }^{3}$ According to article 295 of the Romanian Criminal Procedure Code, the setting in motion of the criminal action takes place only with the preliminary complaint from the injured party in the case of crimes where the law mentions the need for them.

The right of the injured party to make a preliminary complaint is a personal right that is indivisible and non-transferable. The complaint is meant for the criminal investigation body or the prosecutor.

If the complaint is made by a person without any procedural quality, the nullity of the act can be covered through the statement of the injured party, who takes the complaint as his own with the condition that this manifestation of will take place before the lawful deadline expires. ${ }^{4}$

The preliminary complaint, as a special way of notifying, is the procedural act through which the injured party, in our case the parent who was given custody of the child or the parent of the minor, when the minor was entrusted to a different person other than the parents to raise and educate, manifests his will for the offender to be held responsible -

${ }^{1}$ STEFANI, G.; LeVASSEUR, G.; BOULAC, B. (1996). Procedure penale, 16 ed. Paris: Dalloz Publishing House, , p. 1, în CRIŞU, A. (2007). Drept procesual penal. Partea generală. Bucureşti: C.H. Beck Publishing House, Bucureşti, p. 3. 2 VOLONCIU, N. (1996). Tratat de procedură penală. Partea generală, vol. I. Bucureşti: Paideea Publishing House, p. 13.

${ }^{3}$ NEAGU, I. (2009). Tratat de procedură penală. Partea specială. Bucureşti: Universul Juridic Publishing House, p. 71.

${ }^{4}$ CSJ secţia penală, dec. Nr. 1164/1996, în CRIŞU, C.; CRIŞU, Şt. - Practica şi literatura juridică, 1994-1997, p. 575. 
in our case, the parent of the minor or the parent to whom the minor was entrusted, without which the criminal law cannot apply and, in consequence, cannot give start or continue the prosecution.

The preliminary complaint has a mixed judicial nature as it is both an institution of criminal law and one of criminal procedure law. From a criminal law standpoint, the preliminary complaint starts off as a condition for punishment, for punitive measure, while from a procedural law standpoint, it is a condition for the trial to take place. ${ }^{1}$

Because the 192/2006 Law concerning mediation and the organization of the mediator profession mentions that during mediation the parties may be represented by other people that can undertake disposition acts according to the law, we understand the during the mediation procedure the parties may request conventional representation.

\section{Mediation before the start of the prosecution}

The start of the prosecution is a special procedural moment, as it is the initial moment of the criminal trial and it also rights and obligations specific to both the criminal prosecution bodies and also to other participants in the trial².

According to article 296 of the Romanian Criminal Procedure Code, the preliminary complaint must be introduced within 3 months of the day when the injured party learned of the deed. When calculating procedural deadlines, the beginning is usually the hour, day, month or year mentioned in the act that started the timeline, except when the law says otherwise. When calculating deadlines by hours or days, we do not take into account the hour or day when the time starts to pass towards the deadline and neither the hour or day when the deadline is supposed to be. The deadlines calculated by months or years expire, by case, at the end of the day that corresponds to the last month or at the end of the day and month that corresponds to the last year. If this day falls in a month that does not have a corresponding day, the deadline expires in the last day of that month. When the last day falls within a non-working day, the deadline expires on the next working day.

According to article 69 of the 192/2006 Law concerning mediation and the organization of the mediator profession, if the mediation procedure takes place before the criminal trial starts and it ends through the reconciliation of the parties, the injured party can no longer notify the criminal prosecution bodies or the court for the same action. In paragraph (2) it is shown that if the mediation procedure was started in the deadline specified by the law for the introduction of the preliminary complaint, this deadline is suspended for the

1 TEODORU, G. (2008). Tratat de drept processual penal, ed. a II-a. Bucureşti: Hamangiu Publishing House, p. 153.

2 BOROI, A.; UNGUREANU, Ş.G.; JIDOVU, N.; MĂGUREANU, I. (2001). Drept processual penal. Bucureşti: All Beck Publishing House, p. 251. 
duration of the mediation. If the parties in conflict have not reconciled, the injured party can introduce a preliminary complaint in the same deadline, that will start flowing from when it was first interrupted at the moment of drafting the report for the beginning of the mediation procedure, keeping in mind the time that was elapsed until that moment.

\section{Mediation after the beginning of the prosecution}

The prosecution is a phase of the criminal trial that is concerned with the gathering of evidence necessary to prove the existence of crimes, to identify people who have committed a crime and to establish their criminal responsibility in order to decide if they should be sent to trial or not.

We consider that this is the procedural phase in which the parties will go to a mediator in most of the cases. From the standpoint of the offender, the beginning of the prosecution, a moment when he is granted procedural obligations, can constitute an alarm for him, because the criminal prosecution bodies have considered that there is enough evidence and clues towards the existence of the crime and sending the offender on trial is now possible.

If the mediation agreement takes place during the prosecution, the prosecutor shuts down the criminal procedures. As a result, the agreement can be subjected to validation by authentication through notary or by consecration in the court, because the prosecutor does not have any powers except for criminal action.

If the mediation contract has been completed after the start of the prosecution, the criminal trial is suspended until the mediation contract is presented by the parties for a limited time of only 3 months. Because the text refers to presenting the contract, we believe that the date of suspension is not the date when the mediation contract is completed but the date when the parties together, or by themselves present the mediation contract to the criminal prosecution bodies.

The 3 month deadline is a procedural deadline and is calculated according to article 186 of the Romanian Penal Code, expiring at the end of the day corresponding to the last month, and if this day falls in a month without a corresponding day, the deadline expires in the last day of that month. When the last day falls in a non-working day the deadline expires at the end of the first working day to follow.

According to article 70, paragraph (2) of the 192/2006 Law, the suspension lasts until the mediation procedure is closed through any of the ways mentioned by this law, but no longer than 3 months from signing the mediation contract.

The suspension period can stop through the reconciliation of the parties or through withdrawal of the complaint, in which case it will lead to the cessation of the criminal trial, 
if the mediation was successfully finalized within the 3 moth timeframe, allowing the parties can chose to personally present or file the mediation contract in authentic form.

After suspending the prosecution, the prosecutor returns the case file to the criminal investigation bodies or can ask for it to be taken. While the prosecution is suspended, the criminal investigation bodies continue to work on activities that are not prohibited by the situation of the suspect or defendant, respecting the parties' right to a defense or of other procedural subjects. When resuming the prosecution, the acts that were undertaken during suspension can be remade, if possible, at the request of the suspect or defendant ${ }^{1}$.

The criminal investigation body is obligated to periodically check, but not later than 3 months from the start of the suspension, if the causes of the suspension still stand. If he realizes these causes are no longer valid, he immediately informs the prosecutor in order to resume the prosecution.

The mediator is obligated to send the judicial body a copy of the report for the closing of the mediation procedure.

\subsection{Mediation after the notification of the court}

In the case of disrespecting the measures concerning the custody of the minor, mediation can take place at any time during the criminal trial, including during the appeal.

The judgment is the phase of the criminal trial that takes place in front of the courts from the moment of the notification of the preliminary chamber judge and until the definitive ruling on the criminal case.

According to article 551 of the Romanian Criminal Procedure Code, the rulings of the first court are definitive:

1. At the date of the pronouncement, when the ruling is not subject to appeal or contestation;

2. At the date when the deadline for the appeal or introduction of contestation expires:

a) When an appeal or contestation was not declared within the deadline;

b) When the appeal or contestation declared was withdrawn within the deadline;

3. At the date the appeal or contestation was withdrawn, if it took place after the deadline expired.

4. At the date the ruling was pronounced through which the appeal or contestation was rejected.

${ }^{1}$ RADU, M.E. (2014). Drept procesual penal. Partea specială. Bucureşti: Universitară Publishing House, p. 30. 
The purpose of the judgment is to definitively solve criminal cases, which implies a legal, sound ruling, that can be enacted upon so that the purpose of the criminal trial is met ${ }^{1}$.

\section{Mediation in the first instance}

According to article 6 of the European Human Rights Convention and of fundamental freedoms, the judgment in first instance is a mandatory initial stage of judgment, because every person accused in terms of criminal law, has the right for his case to be examined fairly, publicly and within a reasonable timeframe, by an independent and impartial tribunal, organized by the law².

In this stage, procedural activity is no longer conducted by the prosecutor as it was during the prosecution, but by the court, which has the quality of being a dominant subject of the legal context of criminal procedure law ${ }^{3}$.

The parties can agree to start the mediation procedure even after the notification of the court through the indictment act. Because undertaking a court investigation would not too many court terms, it is advisable that the parties communicate to the court their intent to use mediation from the first court term. The court is obligated to recommend that the parties consider the possibility of mediation from the very first court term.

Because the suspension of the criminal trial takes place only after presenting the contract of mediation, we consider it useless when the parties manifest a real intent to resort to mediation in order for the court to provide an additional court term so that the parties can agree on a mediator and sign a mediation contract.

\section{Mediation throughout the means of appeal}

The means of appeal are legal ways through which, at the request of the prosecutor or other people mentioned by the law, a judiciary control method is set in motion in order to remove unlawful or unfounded criminal rulings ${ }^{4}$.

The appeal is an ordinary means of remedy, in fact and in law, which can be used against rulings pronounced in first instance by an inferior court, after it has cleared itself of the case, so that the case is now subject to a new judgment, with the purpose of remedying the contested ruling ${ }^{5}$.

\footnotetext{
1 BOROI, A.; UNGUREANU, Ş.G.; Jidovu, N.; Măgureanu, I. - op. cit., p. 285.

2 TULBURE, A.Ş.; TATU, A.M. (2001). Tratat de drept processual penal. Bucureşti: All Beck Publishing House, p. 349.

3 BOROI, A.; UNGUREANU, Ş.G.; JIDOVU, N.; MĂGUREANU, I. - op. cit., p. 301.

${ }^{4}$ LORINCZ, A.L (2009). Drept procesual penal. Curs universitar. Bucureşti: Universul Juridic Publishing House, p. 386. ${ }^{5}$ PAPADOPOL, V.; TURIANU, C. (1994). Apelul penal. Bucureşti: Casa de editură şi presă ŞANSA-SRL Publishing House, p. 29.
} 
Therefore, if the mediation takes place during the judgment phase, the defendant will be acquitted and the mediation agreement will be taken into account and enacted.

\section{The start of the mediation procedure}

The mediation procedure is regulated by article 50-55, chapter $V$ of the 192/2006 Law concerning mediation and the organization of the mediator profession, entitled "The mediation procedure".

The mediation procedure has a voluntary nature. Even if the judicial bodies have the possibility to recommend to the parties to use the mediation procedure, it is a exclusive prerogative of the parties if they decide to use a mediator and to select the right one by mutual agreement. The agreement can take place at the same time or one after the other. The mediator cannot impose a solution on the parties regarding the conflict that is subject to mediation.

As is mentioned in article 51 of the 192/2006 Law, mediation takes place, usually, at the office of the mediator. If need be, mediation can also take place somewhere else, agreed upon by the mediator and the parties in conflict. The mediator will draw attention to the people participating in the mediation according to article 52 towards the obligation of confidentiality and will request the parties to sign a confidentiality agreement.

If during the mediation, a situation that can damage the purpose of the mediation should arise, or the neutrality or impartiality of the mediator, he is obligated to tell the parties involved who will then decide if they want to keep or denounce the mediation contract.

\section{$5 \quad$ The closing of the mediation procedure}

According to article 56 of the law, the mediation procedure comes to a close when:

a) An agreement is reached between the parties as a result of solving the conflict;

b) The mediator ascertains the failure of the procedure;

c) One of the parties submits the mediation contract.

If the parties have only closed a partial agreement, as is mentioned in paragraph (1), letters b) and c), any party can go in front of the court.

When the mediation procedure is closed, for any of the cases mentioned above, the mediator will redact a report that is signed by both parties, personally or through representative, and by the mediator. The parties each receive an original copy of the report.

When the parties in conflict have reached an understanding, an agreement can be redacted in writing, that will include all the clauses agreed upon by them and that will 
have the value of a document under private signature. Usually, the agreement is redacted by the mediator, with the exception of situations when the parties and the mediator agree differently.

According to article 59 of the 192/2006 Law, the parties can solicit a public notary to authenticate their understanding. Also, the parties can appear before the court to request that a ruling be given to consecrate their agreement. The competency belongs either to the court in whose jurisdiction the domicile, residence or headquarters of any of the parties resides or the court in whose jurisdiction resides the place where the mediation took place. The ruling through which the court validates the agreement of the parties is given in the counsel chambers and constitutes an executor title according to the law.

During any stage of the mediation procedure, any of the parties in conflict, the parent of the minor or the person to whom the custody was entrusted to (active subject) and the parent who the minor was entrusted to or the parent of the minor, when his custody was given to a different person, other than the parents to raise and educate (passive subject), has the right to denounce the mediation contract, notifying in writing the other party and the mediator. In these conditions, the mediator takes note of the unilateral denunciation of the mediation contract and within 48 hours must file a report for closing the mediation procedure.

When one of the parties in conflict no longer shows up for mediation, without denouncing the mediation contract as stated above, the mediator is forced to take all necessary steps to figure out the real intent of that party and to decide whether to continue or close the mediation procedure.

According to article 61, paragraph (2) of the law, when closing the mediation procedure, the mediator is obligated, in all cases, to let the competent court know about the mediation agreement and the report of the mediation closing providing an original document and one in electronic format if the parties have come to an understanding or just the mediation closing report in the cases mentioned in article 56, paragraph (1), letters b) and c).

\section{Conclusions}

The reason why the legislator opted to limit the mediation procedure to certain crimes, among which is the disrespecting of measures concerning the custody of the minor is the fact that even without a mediation process, the parties can reach an agreement concerning the crime and its consequences, the will of the parties being an essential element both in the beginning of the criminal trial and in the ending. The principle of ex officio for criminal trials is limited, obviously, by the will of the parties. 
Theoretically, mediation in terms of criminal law represents a major evolution in the criminal procedures. Through this institution, the victim plays a greater role in the unfolding of proceedings and can find satisfaction faster through quicker procedures and repair the damages, and the offender can consider the damage he has caused and accept to repair it, society allowing him to reintegrate through other ways than by isolation in a detention facility.

Mediation in terms of criminal law is a conflict solving technique that intervenes in a constructive manner, both for the offender and for the victim. Moreover, this shows a new way of thinking for the criminal justice system which is dealing with difficulties in terms of efficiency and managing the high volume of trials. Thus, through mediation the conflict is solved and it allows the judicial bodies to resolve complex cases and of much higher difficulty.

Mediation presents certain advantages for the parties involved, such as the fact that the decision belongs to them, it has a positive effect on the relationship between the parties, it is informed and implies confidentiality and it is also faster and involves considerably less costs than a trial.

Criminal mediation can only be done by an authorized mediator based on the 192/2006 Law concerning mediation and the organization of the mediator profession. Criminal mediation can be undertaken only during a professional procedure that begins by soliciting mediation through a mediation readiness contract, sending an invitation to the mediation, discussing mediation with all the people involved in the criminal conflict, signing the mediation contract, redacting a closing report for the mediation and, if an agreement is reached, signing the mediation agreement. Only an authorized and active mediator may undertake a mediation with all its stages. After the mediation, the mediator is obligated to send the mediation closing report and the mediation agreement to the judicial bodies where the criminal file in question is kept. The mediation agreement is in fact a civil understanding between the injured party and the suspect. The mediator facilitates the understanding between the parties and not a reconciliation. The understanding can take different forms, can be conditioned, can have various stipulations, can contain any type of agreement between the parties, if the agreement is within moral and legal bounds. In other words the mediation agreement is a private contract between the people in the criminal conflict, a contract that is subject to the rules of civil contracts.

The effects in terms of criminal law of the mediation agreement lead to the cessation of the criminal trial. These take place lawfully and are not subject to the will of the prosecutor or the judge. Therefore, the mediation agreement stops the criminal trial by law, when the prosecutor or the judge is made aware of it and is not left to the willingness of the prosecutor or the judge whether to stop the trial or not, when the mediation agreement between the parent of the minor or the person who the custody was entrusted 
to and the parent who was entrusted with the child or the minor's parent, when someone else was granted custody other than the parents, is submitted to the criminal file.

\section{References}

BOROI, A.; UNGUREANU, Ş.G.; JIDOVU, N.; MĂGUREANU, I. (2001). Drept processual penal. Bucureşti: All Beck Publishing House, p. 251.

CRIŞU, C.; CRIŞU, Şt. - Practica şi literatura juridică, 1994-1997, p. 575.

DRAGNE, L.; TRANCĂ, A. (2011). Medierea în materie penală. Bucureşti: Universul Juridic Publishing House, p. 111.

FISCUCI, I.C. (2012). Aspecte particulare în aplicarea medierii în disputele din domeniul penal, Revista Română de ADR, no 1, p. 23.

IONAŞCU, A.; MUREŞAN, M.; COSTIN, M.; URSA, V. (1975) Familie şi rolul ei în societate. Cluj: Dacia Publishing House, p. 5.

LAW NO 192/2006 CONCERNING MEDIATION AND THE ORGANIZATION OF THE MEDIATOR PROFESSION, published in Official Gazette of Romania, Part I, no 441 from 22 May 2006, with ulterior modifications.

LORINCZ, A.L (2009). Drept procesual penal. Curs universitar. Bucureşti: Universul Juridic Publishing House, p. 386.

MATEUȚ, G. (2007). Medierea penală, in Dreptul no 7, p. 149.

NEAGU, I. (2009). Tratat de procedură penală. Partea specială. Bucureşti: Universul Juridic Publishing House, p. 71.

OANCEA, I. în DONGOROZ, V. și colab. (2003). Explicații teoretice ale Codului penal român. Partea specială, vol. IV, ed. a 2-a, Bucureşti: All Beck Publishing House, p. 521.

PAPADOPOL, V.; TURIANU, C. (1994). Apelul penal. Bucureşti: Casa de editură şi presă ŞANSA-SRL Publishing House, p. 29.

POPESCU, T. (1965). Dreptul familiei. Tratat, vol. I. Bucureşti: Didactică şi Pedagogică Publishing House, p. 17.

RADU, M.E. (2014). Drept procesual penal. Partea specială. Bucureşti: Universitară Publishing House, p. 30.

ROMANIAN CIVIL CODE

ROMANIAN PENAL CODE

ROMANIAN CRIMINAL PROCEDURE CODE 
STEFANI, G.; LEVASSEUR, G.; BOULAC, B. (1996). Procedure penale, 16 ed. Paris: Dalloz Publishing House, , p. 1, în CRIŞU, A. (2007). Drept procesual penal. Partea generală. Bucureşti: C.H. Beck Publishing House, Bucureşti, p. 3.

TEODORU, G. (2008). Tratat de drept processual penal, ed. a II-a. Bucureşti: Hamangiu Publishing House, p. 153.

TOMESCU, M; MURARU, I.; TĂNĂSESCU, E.S. (2008). Constituția României. Comentariu pe articole. Bucureşti: C.H. Beck Publishing House, București, p. 496.

TULBURE, A.Ş.; TATU, A.M. (2001). Tratat de drept processual penal. Bucureşti: All Beck Publishing House, p. 349.

VOLONCIU, N. (1996). Tratat de procedură penală. Partea generală, vol. I. Bucureşti: Paideea Publishing House, p. 13. 